\title{
PENGARUH PEMBUATAN MIND MAPPING TERHADAP HASIL BELAJAR SISWA PADA PEMBELAJARAN PENDIDIKAN KEWARGANEGARAAN (PKn) KELAS V SD
}

\author{
Afriani Hajjiah ${ }^{1)}$, Mayarnimar ${ }^{2)}$, Reinita ${ }^{3)}$ \\ ${ }^{1)}$ Mahasiswa, Universitas Negeri Padang, Indonesia \\ 2) Pembimbing 1, Universitas Negeri Padang, Indonesia \\ 3) Pembimbing 2, Universitas Negeri Padang, Indonesia \\ ${ }^{1)}$ afrianihajjiah38@gmail.com, ${ }^{2)}$ mayar.nimar@yahoo.co.id \\ 3)reinita_reinita@yahoo.com
}

\begin{abstract}
ABSTRAK
Penelitian ini dilatarbelakangi oleh pembelajaran pendidikan kewarganegaraan $(\mathrm{PKn})$ yang masih didominasi oleh guru dalam penyampaian materi pembelajaran serta sarana dan prasarana di sekolah kurang memadai. Penelitian ini bertujuan untuk mengetahui pengaruh pembuatan Mind Mapping terhadap hasil belajar pendidikan kewarganegaraan (PKn).

Jenis penelitian adalah kuantitatif dengan metode penelitian yang digunakan dalam penelitian ini adalah penelitian eksprimen. Teknik pengambilan sampel menggunakan teknik sampling jenuh. Sampel dalam penelitian ini berjumlah 60. Teknik analisis data dalam penenlitian ini menggunakan uji prasyarat yang berupa uji normalitas, uji homogenitas, dan uji hipotesis menggunakan uji-t.

Berdasarkan hasil penelitian diperoleh nilai rata-rata nilai pretest sebesar 56.26 untuk kelas eksperimen sebesar 64.13 untuk kelas control. Rata-rata nilai posttest sebesar 80.8 untuk kelas eksperimen dan sebesar 72,4 untuk kelas control. Berdasarkan perhitungan uji-t diperoleh bahwa $t_{\text {hitung }}>t_{\text {tabel }}(3,019>1,67)$, pada taraf signifikan 0,05 .
\end{abstract}

Kata Kunci : Mind Mapping, Pembelajaran PKn

\begin{abstract}
This research aims to determine the effect of the use of Mind Mapping on the results of learning Pkn five grade students SD Negeri 54 Anak Air Kec. Koto Tangah Padang. This research is a type of experimental research in the form of Quasi Experimental Type Nonequivalent Control Group Design. The sampling technique using total sampling technique with the sample number 60 students. This is evidenced from the results of t-test with significance level of $5 \%$ obtained tcount $(3,019>1,67155)$. The result of Civic learning obtained by the experimental group is higher than the control group, it is shown from mean 80,8 and the mean obtained by the control group is 72,4 .
\end{abstract}

Keyword: Mind Mapping, Civict Studies

1 | e-Journal Inovasi Pembelajaran SD | http://ejournal.unp.ac.id/index.php/pd | 


\section{PENDAHULUAN}

Mind Mapping merupakan salah satu cara mencatat materi pelajaran yang memudahkan siswa untuk mengingat pelajaran dan membantu siswa belajar, menyusun, menyimpan sebanyak mungkin informasi dan member siswa cara yang mudah dan langsung (ingatan yang sempurna) terhadap materi yang akan dipelajari. Dimana cara ini mengembangkan kegiatan berpikir ke segala arah dan mengembangkan cara berpikir kreatif.

Mind Mapping juga disebut alat berpikir kreatif yang sangat hebat yang juga merupakan cara termudah untuk menempatkan informasi ke dalam dan mengambil informasi itu ketika dibutuhkan. Menurut Buzan (2005:40 "Mind Mapping adalah cara termudah untuk menempatkan informasi ke dalam otak dan mengambil informasi ke luar otak".

Mind Mapping membuat kita bisa menyusun fakta dan pikiran sedemikian rupa sehingga cara kerja otak kita yang alami akan dilibatkan sejak awal sehingga informasi akan lebih mudah dan bisa diandalkan dari pada menggunakan teknik catat biasa". Ini berarti mengingat informasi akan lebih mudah dan lebih bisa diandalkan dari pada menggunakan pencatatan tradisional.

Kelebihan Mind Mapping adalah pembelajaran akan menjadi menarik dimana yang di awali dari suatu permasalahan yang nyata dan melatih pola pikir siswa sehingga mengeluarkan ide-ide atau gagasan yang baik dan sistematis. Selain itu, Mind Mapping juga mengajari siswa untuk dapat menimbulkan rasa tanggung jawab dalam menyelesaikan masalah. Seperti yang diungkapkan Istarani (2014:59-60) "menyebutkan kelebihan Mind Mapping adalah Pembelajaran akan menarik sebab diawali dari suatu permasalahan yang actual, dapat melatih alur pikir siswa yang relevan dengan kajian permasalahan, dapat meningkatkan kerjasama antara siswa karena pembelajaran dilakukan dalam kelompok, dimungkinkan siswa untuk mengeluarkan idea atau gagasannya secara baik dan sistematis, dimungkinkan siswa mengetahui kompetensinya, sejauh mana kemampuan yang ia miliki".

Mind Mapping mampu meningkatkan ketertarikan siswa dalam belajar dan siswa dapat mengeluarkan ide-ide atau gagasan baru dalam pembelajaran sehingga siswa aktif dalam mengikuti proses pembelajaran. Maka dengan keunggulan tersebut dapat dipastikan Mind Mapping sangat cocok 2 | e-Journal Inovasi Pembelajaran SD | http://ejournal.unp.ac.id/index.php/pd | 
digunakan dalam pembelajaran pendidikan kewarganegaraan (PKn).

Pendidikan

Kewarganegaraan

(PKn) adalah suatu mata pelajaran yang lebih memfokuskan pada usaha untuk memberikan pemahaman kepada peserta didik guna membentuk peserta didik menjadi warga negara yang memiliki nilai luhur dalam menjalankan hak dan kewajibannya sebagai warga negara Indonesia yang cerdas, terampil, dan berkarakter yang telah diamanatkan oleh Pancasila dan UUD 1945. Oleh sebabitu, Pendidikan Kewarganegaraan merupakan salah satu pembelajaran yang wajib untuk dikuasai peserta didik di sekolah dasar.

Mata pelajaran Pendidikan Kewarganegaraan (PKn) digunakan sebagai wadah untuk mengembangkan dan melestarikan nilai luhur dan moral yang berakar pada budaya bangsa Indonesia. Nilai luhur dan moral ini diharapkan dapat diwujudkan dalam bentuk perilaku kehidupan siswa sehari-hari, baik sebagai individu maupun sebagai anggota masyarakat, dan makhluk ciptaan Tuhan Yang Maha Esa, yang merupakan usaha untuk membekali siswa dengan pengetahuan dan kemampuan dasar berkenaan dengan hubungan antarwarga dengan negara serta pendidikan pendahuluan bela negara agar menjadi warga negara yang dapat dihandalkan oleh bangsa dan negara. (Susanto, 2013:225).

Tujuan

Pendidikan

Kewarganegaraan di Sekolah Dasar diantarnya untuk membentuk peserta didik menjadi warga negara yang memahami dan mampu menjalankan hak dan kewajibannya sebagai warga negara Indonesia. Salah satu kewajiban sebagai warga negara indonesia yaitu menjaga keutuhan Negara Kesatuan Republik Indonesian. Selain itu, Pendidikan Kewarganegaraan (PKn) mempunyai tujuan untuk membantu siswa membentuk watak atau karakteristik warga negara yang baik, memiliki kemampuan berfikir kritis, rasional dan logis. Hal ini sesuai dengan pernyataan Depdiknas (2006:271) yang menyebutkan tujuan PKn diantaranya yaitu:

1). Berpikir secra kritis, rasional, dan kreatif dalam menanggapi isu kewarganegaraan. 2). Berpartisipasi secra aktif dan bertanggung jawab dan bertindak secara cerdas dalam kegiatan bermasyarakat, berbangsa, dan bernegara serta antikorupsi. 3). Berkembang secara positif dan demokratis untuk membentuk diri berdasarkan

3 | e-Journal Inovasi Pembelajaran SD | http://ejournal.unp.ac.id/index.php/pd | 
karakter-karakter masyarakat Indonesia agar dapat hidup bersama dengan bangsa-bangsa lain. 4). Berinteraksi dengan bangsa-bangsa lain dalam pencaturan dunia secara langsung atau tidak langsung dengan memanfaatkan teknologi informasi dan komunikasi.

Terwujudnya tujuan pembelajaran Pkn tersebut tidak terlepas dari mutu pendidikan yang diusahakan guru disekolah. Guru dituntut untuk membantu siswa berpikir kritis dan rasional sehingga melahirkan sikap yang bertanggung jawab, mampu mengembangkan sikap yang positif dan demokratis di dalam kehidupan bermasyarakat, berbangsa dan bernegara.

Fakta dilapangan yang ditemukan peneliti saat melakukan observasi yang peneliti lakukan pada tanggal 16 Februari 2018 di SDN 54 Anak Air Kec. Koto Tangah Padang, diperoleh data yang menunjukan bahwa di dalam proses pembelajaran guru lebih mendominasi dalam penyampaian materi, dimana siswa cenderung hanya mendengarkan apa yang dibicarakan atau dijelaskan oleh guru (guru yang terlihat aktif dalam pembelajaran), guru cenderung membacakan materi yang ada di dalam buku paket serta siswa kurang dilibatkan secara keseluruhan selama proses pembelajaran berlangsung baik itu interaksi siswa dengan guru maupun siswa dengan siswa itu sendiri sehingga siswa dengan siswa tidak mau saling berbagi informasi kepada temannya, dan siswa tidak punya keberanian untuk mengemukakan ide-ide atau pendapat dalam pembelajaran yang mengakibatkan siswa bosan dan tidak tertarik mengikuti pelajaran sehingga memberikan pengaruh yang kurang baik terhadap hasil belajar PKn siswa. Selain itu, sarana dan prasarana di sekolah tersebut kurang memadai. Contohnya tidak ada tersedianya computer, infokus, dan meja dan kursi siswa banyak yang rusak. Selain itu, tanah lapangan atau halaman sekolah yang sangat sempit atau kurang luas yang mengakibatkan siswa atau warga sekolah kurang leluasa untuk melaksanakan aktivitas di lapangan sekolah. Dan lingkungan sekolah yang kurang strategis, dimana lingkungan sekolah berada di tepi jalan yang mengakibatkan siswa kurang aman apabila keluar jam istirahat.

Peneliti juga melakukan wawancara dengan guru kelas $\mathrm{V}$ yaitu guru jelas V A dan kelas V B di SDN 54 Anak Air Kec. Koto Tangah Padang yang dilaksanakan 
Pada tanggal tanggal 16

Februari 2018 dari hasil wawancara didapatkan bahwa guru tersebut belum pernah menggunakan Mind Mapping dalam proses pembelajaran khususnya mata pelajaran PKn. Padahal Mind Mapping merupakan salah satu inovasi pembelajaran yang dapat membantu siswa untuk mencapai hasil belajar yang optimal.

$\begin{array}{ccc} & \text { Penggunaan } & \text { Mind Mapping } \\ \text { dapat menjadi inovasi dar }\end{array}$
permasalahan yang terjadi di atas. Hal ini diperkuat dengan penelitian yang telah dilakukan oleh Adi Saputra, dkk yang berjudul Pengaruh Mind Mapping Terhadap Hasil Belajar Peserta Didik Dalam PKn Kelas V SD. Hasil penelitiannya menunjukkan adanya pengaruh terhadap hasil belajar siswa dengan menggunakan Mind Mapping. Hasil penelitiannya menunjukkan terdapat pengaruh signitifikan terhadap hasil belajar siswa dengan menggunaka Mind Mapping dibandingkan dengan hasil belajar siswa yang menggunakan model konvensional. Hal ini terlihat perbedaan bilai rata-rata hasil belajar siswa kelompok eksprimen lebih tinggi dari kelompok control yaitu $75,26>69,42$.

\begin{tabular}{llr}
\multicolumn{2}{c}{ Berdasarkan uraian latar } \\
belakang diatas, maka \\
permasalahan yang dapat \\
diidentifikasi sebagai berikut:1)
\end{tabular}

Guru lebih mendominasi dalam penyampaian materi (guru lebih aktif dalam pembelajaran daripada siswa) 2) Guru cenderung membacakan materi yang ada di dalam buku paket 3) Siswa kurang dilibatkan secara keseluruhan selama proses pembelajaran berlangsung, baik interaksi siswa dengan guru maupun siswa dengan siswa itu sendiri 4) Siswa tidak punya keberanian mengemukakan ide-ide atau pendapat dalam pembelajaran. 5) Siswa bosan dan tidak tertarik mengikuti pelajaran 6) Guru belum pernah menggunakan Mind Mapping dalam pembelajaran 7) Sarana dan prasarana yang kurang memadai 8) Lingkungan sekolah kurang strategis.

Terkait dengan beberapa masalah tersebut diatas karena keterbatasan waktu penelitian serta agar penelitian lebih terarah, maka perlu dibuat pembatasan permasalahan yang akan diteliti, yaitu "Pengaruh pembuatan Mind Mapping Terhadap Hasil Belajar Siswa pada Pembelajaran PKn di Kelas V SDN 54 Anak Air Kec. Koto Tangah Padang". 
Penelitian ini bertujuan untuk untuk mengetahui apakah terdapat pengaruh penggunaan pembuatan Mind Mapping terhadap hasil belajar Pendidikan Kewarganegaraan (PKn) Kelas V di SDN 54 Anak Air Kec. Koto Tangah Padang.

\section{METODOLOGI PENELITIAN}

Penelitian ini menggunakan penelitian kuantitatif. Penelitian kuantitatif adalah penelitian yang dilakukan dengan mengumpulkan data berupa kuantitatif dan diolah dengan menggunakan teknik statistic(Yusuf,2014:43) Jenis penelitian yang dipakai adalah penelitian eksprimen. Menurut Sugiyono (2009:72) penelitian eksperimen dapat diartikan sebagai metode penelitian yang digunakan untuk mencari pengaruh perlakuan tertentu terhadap yang lain dalam kondisi yang terkendalikan.

Metode penelitian yang digunakan dalam penelitian ini adalah penelitian eksprimen yaitu quasi eskperimental design dengan menggunakan Noneequivalent Control Group Design. Menurut Sugiyono (2009:77) "quasi eksperimen design adalah "Suatu desain penelitian yang mempunyai kelompok kontrol, tetapi tidak dapat berfungsi sepenuhnya mengontrol variabel-variabel luar yang mempengaruhi pelaksanaan eksperimen". Oleh karena itu dalam pelaksanaannya menggunakan dua kelompok yang dijadikan sampel, yaitu kelas eksperimen dan kelas control.

Dalam penelitian ini digunakan desain quasi eksprimen design bentuk Nonequivalent Control Group Design, yaitu desain eksprimen quasi yang menggunakan pretest sebelum diberikan perlakuan, dan posttest setelah dilakukan perlakuan yang dapat di gambarkan sebagai berikut:.

Tabel 3.1.Desain Penelitian

\begin{tabular}{|l|c|c|c|}
\hline Kelompok & Pre-test & Perlakuan & Post-test \\
\hline $\begin{array}{l}\text { Eksperim } \\
\text { en }\end{array}$ & $\mathrm{O}_{1}$ & $\mathrm{X}$ & $\mathrm{O}_{2}$ \\
\hline Kontrol & $\mathrm{O}_{3}$ & - & $\mathrm{O}_{4}$ \\
\hline
\end{tabular}

(Sugiyono, 2012 116)

Keterangan :

X: Pembuatan Mind Mapping.

O1:Pretest (tes berupa soal sebelum pembelajaran dengan menggunakan Mind Mapping)

O2 :Post-test (tes berupa soal sesudah pembelajaran dengan menggunakan Mind Mapping).

O3 :Pre-test (tes berupa soal sebelum pembelajaran dengan menggunakan model pembelajaran konvensional)

O4 :Post-test (tes berupa soal sesudah pembelajaran dengan menggunakan model pembelajaran konvensional).

(Sugiyono, 2012: 116) 
Populasi merupakan keseluruhan objek atau subjek yang menjadi sasaran atau sumber data penelitian. Maka populasi pada penelitian ini adalah seluruh siswa kelas V SDN 54 Anak Air Kec. Koto Tangah Padang yaitu kelas V A dengan jumlah 30 siswa dan kelas V B dengan jumlah 30 siswa.

Teknik pengambilan sampel yang digunakan dalam penenlitian ini adalah teknik non probability yaitu dengan jenis sampling jenuh. Sampling jenuh adalah teknik penentuan sampel bila semua anggota populasi digunakan sebagai sampel. (Sugiyono, 2009:85)

Instrumen tes yang digunakan dalam penelitian ini yaitu berupa tes tertulis dalam bentuk tes soal objektif berupa soal pilihan ganda yang berjumlah 30 soal sebelum diuji coba dengan empat alternative pilihan jawaban a, b, c, d. soal yang akan diuji cobakan dilakukan terhadap siswa di luar sampel. Uji coba soal ini dilakukan agar diperoleh pula hasil yang valid dan reliabel. Selain itu, juga dilakukan tingkat kesukaran dan daya beda agar instrument benar-benar dikatakan layak dan baik. Soal yang telah diuji cobakan akan diajukan pada pretest dan posttest pada kelas eksprimen maupun kelas control.

\section{HASIL PENELITIAN}

Pretest dilakukan dengan tujuan untuk mengukur pengetahuan awal siswa mengenai pelajaran pendidikan kewarganegaraan pada materi mendeskripsikan NKRI diperoleh data sebagai berikut:

1. Deskripsi Data Pretest Eksperimen dan Kelas Kontrol

\begin{tabular}{|c|c|c|}
\hline \multirow{2}{*}{$\begin{array}{c}\text { Deskrip } \\
\text { si }\end{array}$} & \multicolumn{2}{|c|}{ Pretest } \\
\hline & $\begin{array}{c}\text { Kelas } \\
\text { Eksperi } \\
\text { men }\end{array}$ & $\begin{array}{c}\text { Kelas } \\
\text { Kontrol }\end{array}$ \\
\hline $\mathbf{N}$ & 30 & 30 \\
\hline $\begin{array}{c}\text { Minim } \\
\text { um }\end{array}$ & 20 & 36 \\
\hline $\begin{array}{c}\text { Maksi } \\
\text { mum }\end{array}$ & 80 & 80 \\
\hline Mean & 56.26667 & 64.13333 \\
\hline Median & 57 & 72,5 \\
\hline Modus & 56,5 & 74 \\
\hline Varians & 265.8575 & 167.154 \\
\hline $\begin{array}{c}\text { Simpan } \\
\text { gan } \\
\text { Baku } \\
\end{array}$ & $\begin{array}{c}16,30513 \\
7227\end{array}$ & $\begin{array}{c}12,92880 \\
5049\end{array}$ \\
\hline
\end{tabular}

Berdasarkan tabel 4.2 di atas, menunjukan hasil pretest kedua kelas. Terlihat bahwa pada kelas eksperimen nilai minimum adalah 20, nilai maksimum adalah 80 , rata-rata 56.26667 , median 57, modus 56,5 varian 265.8575, dan simpangan bakunya 16,305137227. Sedangkan pada kelas kontrol nilai minimum 36 nilai maksimum 80, ratarata 64.13333 , median 72,5 , modus 74 , varian 167.154, dan simpangan bakunya 12,928805049. Kelas yang akan diajarkan dengan menggunakan Mind Mapping yaitu kelas eksperimen memiliki kemampuan yang sama 
dengan kelas yang akan diajarkan dengan menggunakan pembelajaran konvensional yaitu kelas kontrol.

2. Deskripsi Data Postest Pada Kelas Eksperimen dan Kelas Kontrol

Setelah masing-masing kelas melakukan proses belajar dengan perlakuan yang berbeda selanjutnya dilakukan posttest yang bertujuan untuk mengukur sejauh mana kemampuan akhir dan hasil belajar siswa.

\begin{tabular}{|c|c|c|}
\hline \multirow{2}{*}{ Deskripsi } & \multicolumn{2}{|c|}{ Posttest } \\
\cline { 2 - 3 } & $\begin{array}{c}\text { Kelas } \\
\text { Eksperime } \\
\text { n }\end{array}$ & $\begin{array}{c}\text { Kelas } \\
\text { Kontrol }\end{array}$ \\
\hline $\mathbf{N}$ & 30 & 30 \\
\hline Minimum & 64 & 52 \\
\hline Maksimum & 100 & 92 \\
\hline Mean & 80,8 & 72,4 \\
\hline Median & 88 & 73,5 \\
\hline Modus & 95 & 72,3 \\
\hline Varians & 119.6138 & 138.3172 \\
\hline Simpangan & 10,9368094 & 11,76083 \\
Baku & 07 & 3304 \\
\hline
\end{tabular}

Berdasarkan tabel 4.4 di

atas, menunjukan hasil posttest

kedua kelas. Terlihat bahwa pada

kelas eksperimen nilai minimum adalah 64 , nilai maksimum adalah 100, rata-rata 80,8 , median 88 , modus 95, varian 119,6138, dan simpangan bakunya 10,936809407. Sedangkan pada kelas kontrol nilai minimum 52, nilai maksimum 92, rata-rata 72,4,median 73,5, modus 72,3 , varian 138,3172 , dan simpangan bakunya 11,760833304. Hal ini menunjukan nilai rata-rata kedua kelas menunjukan perbedaan yang signifikan yaitu kelas eksperimen 80,8, untuk kelas kontrol yaitu 72,4. Maka perolehan nilai posttest kelas eksperimen lebih tinggi dari pada kelas kontrol.

B. Pengujian Persyaratan Analisis dan Pengujian Hipotesis.

a. Uji Normalitas data pretest

Uji normalitas pada tes awal dilakukan dengan menggunakan uji Liliefors pada taraf signifikan $\alpha=0.05$, sedangkan data yang digunakan adalah hasil belajar pendidikan kewarganegaraan pada materi mengenal bentuk-bentuk keputusan bersama.

Uji normalitas digunakan untuk mengetahui apakah data berdistribusi normal atau tidak, dengan ketentuan bahwa data berdistribusi normal bila Lhitung $<$ Ltabel dengan kriteria tabel

8 | e-Journal Inovasi Pembelajaran SD | http://ejournal.unp.ac.id/index.php/pd | 
diukur pada taraf signifikansi dan tingkat kepercayaan tertentu.

Tabel 4.5. Deskripsi Data Pretest Uji Normalitas Kelas Eksperimen dan Kelas Kontrol

\begin{tabular}{|c|c|c|}
\hline \multirow[t]{2}{*}{ Statistic } & \multicolumn{2}{|c|}{ Pretest } \\
\hline & Eksprimen & Kontrol \\
\hline Banyak & 30 & 30 \\
\hline sampel & & \\
\hline Lhitung & 0.023886 & 0.041265 \\
\hline Ltabel & 0,161 & 0,161 \\
\hline Kesimpulan & Normal & Normal \\
\hline
\end{tabular}

Dari hasil hitung uji normalitas pada kelas eksperimen diperoleh $0.023886<0,161$ atau $\mathrm{L}_{\text {hitung }}$ lebih kecil dari $\mathrm{L}_{\text {tabel }}$ pada taraf signifikan $\alpha=0.05$ untuk $n=30$. Sedangkan uji normalitas pada kelas kontrol diperoleh $0.041265<0,161$ atau $L_{\text {hitung }}$ lebih kecil dari $\mathrm{L}_{\text {tabel }}$ pada taraf signifikan $\alpha=0.05$ untuk $n=30$. Karena $\mathrm{L}_{\text {hitung }}$ lebih kecil dari $\mathrm{L}_{\text {tabel }}$ maka dapat dikatakan bahwa data pretest kelas eksperimen dan kelas kontrol berdistribusi normal.

\section{b. Uji homogenitas data pretest}

Pengujian homogenitas varians dua kelompok perlakuan pada penelitian ini dilakukan dengan menghitung $F_{\text {hitung }}$ antara varians terbesar dan varians terkecil dari kedua kelas yang diuji. Perhitungannya yaitu dengan cara membagi antara varians terbesar dengan varians terkecil dari kelompok yang diuji, kemudian dibandingkan dengan $F_{\text {tabel }}$ pada taraf signifikan $\alpha=0.05$ dari derajat kebebasan pembilang 29 dan penyebut 29 sebesar 1,67.

\begin{tabular}{|l|c|c|}
\hline \multirow{2}{*}{$\begin{array}{c}\text { Data } \\
\text { Statistik }\end{array}$} & $\begin{array}{c}\text { Kelomp } \\
\text { ok } \\
\text { Eksprim } \\
\text { en }\end{array}$ & $\begin{array}{c}\text { Kelompo } \\
\text { k Kontrol }\end{array}$ \\
\hline Varian & 265.8575 & 167.154 \\
\hline $\begin{array}{l}\text { Varian } \\
\text { Terbesar }\end{array}$ & \multicolumn{2}{|c|}{265.8575} \\
\hline $\begin{array}{l}\text { Varian } \\
\text { Terkecil }\end{array}$ & \multicolumn{2}{|c|}{167.154} \\
\hline Fhitung & \multicolumn{2}{|c|}{1,590} \\
\hline Ftabel & \multicolumn{2}{|c|}{1,67} \\
\hline Kesimpulan & \multicolumn{2}{|c|}{ Homogen } \\
\hline
\end{tabular}

Berdasarkan hasil perhitungan uji homogenitas pretest sebesar 1,590, sedangkan $\mathrm{F}_{\text {tabel }}$ dengan $(29 ; 29 ; 0,05)=1,67$. Jika dibandingkan, maka $F_{\text {hitung }}$ lebih kecil dari $\mathrm{F}_{\text {tabel }}$ atau 1,590 $<1,67$. Dengan demikian dua kelompok siswa yaitu kelas eksperimen dan kelas kontrol pada pretest adalah homogen.

\section{c. Uji Data Pretest}

Pada uji-t nilai pretest tampak bahwa $\mathrm{T}_{\text {hitung }}<\mathrm{T}_{\text {tabel }}$ yaitu $\quad-218,091<1,67155$ sehingga hipotesis nol (Ho) diterima 
dan hipotesis alternatif (Ha) ditolak. Maka tidak terdapat perbedaan yang signifikan antar hasil pretest kelas VA sebagai kelas eksperimen dan VB sebagai kelas kontrol.

Artinya kedua kelas memiliki kemampuan yang homogen dan kedua kelas layak dijadikan sampel penelitian.

\section{d. Uji homogenitas data Postest}

\begin{abstract}
Perhitungannya yakni dengan cara membagi antara varians terbesar dengan varians terkecil dari kelompok yang diuji, kemudian dibandingkan dengan $F_{\text {tabel }}$ pada taraf signifikan $\alpha=0.05$ dari derajat kebebasan pembilang 29 dan penyebut 29 sebesar 1,67.
\end{abstract}

Berdasarkan hasil perhitungan uji homogenitas postest sebesar 1,156, sedangkan $F_{\text {tabel }}$ dengan $(29 ; 29 ; 0,05)=1,67 . \quad$ Jika dibandingkan, maka $\mathrm{F}_{\text {hitung }}$ lebih kecil dari Ftabel atau 1,156<1,67. Hal ini berarti Ha diterima. Dengan demikian dua kelompok siswa kelas eksperimen dan kelas kontrol pada postest adalah homogen.

\section{f.Hasil Uji Hipotesis}

Pengujian hipotesis dilakukan untuk mengetahui apakah hipotesis yang diajukan ditolak atau diterima. Setelah data posttest hasil belajar pendidikan kewarganegaraan baik pada kelas eksperimen maupun kelas kontrol dianggap berdistribusi normal dan memiliki varians yang homogen maka dilakukan uji hipotesis. Uji-t pada data posttest bertujuan untuk mengetahui apakah ada pengaruh dari Mind Mapping yang digunakan dalam pembelajaran atau tidak.

Uji prasyarat analisis data normalitas dan homogenitas menyatakan bahwa kedua sampel dalam keadaan normal dan homogen, sehingga perhitungan analisis data dapat dilakukan dengan menggunakan rumus uji t, pada taraf signifikasi $5 \%$ dan "df $/ \mathrm{db}=\mathrm{n} 1+\mathrm{n} 2-2$ " dengan kriteria yaitu $\left(\mathrm{T}_{\text {hitung }}>\right.$ $\mathrm{T}_{\text {tabel }}=$ Ha diterima $)$ dan $\left(\mathrm{t}_{\text {hitung }}<\right.$ $\mathrm{t}_{\text {tabel }}=$ Ha ditolak $)$.

\begin{tabular}{|l|c|c|}
\hline \multicolumn{1}{|c|}{ Keterangan } & \multicolumn{2}{c|}{ Posttest } \\
\hline $\mathrm{N}$ & $\begin{array}{c}\text { Eksperi } \\
\text { men }\end{array}$ & Kontrol \\
\hline Rata-rata & 30 & 30 \\
\hline $\mathrm{T}_{\text {hitung }}$ & \multicolumn{2}{|c|}{$30,2,44$} \\
\hline $\mathrm{T}_{\text {tabel }}$ & \multicolumn{2}{|c|}{1,67155} \\
\hline Kesimpulan & Terdapat Pengaruh \\
\hline \multicolumn{2}{|c|}{ Nilai posttest $=3,019$ dan } \\
\multicolumn{2}{|c|}{$\mathrm{T}_{\text {tabel }}=1,67 \quad$ dengan taraf } \\
signifikasi $0.05 \quad$ dan derajat \\
kebebasan (df/db = 30+30 - 2 = \\
58) ini menunjukan bahwa
\end{tabular}


$\mathrm{T}_{\text {hitung }}>\mathrm{T}_{\text {tabel }}$ atau $3,019>1,67$ dengan demikian maka $\mathrm{H}_{\mathrm{o}}$ ditolak, $\mathrm{H}_{\mathrm{a}}$ diterima maka dapat dikatakan bahwa data posttest atau tes akhir menunjukan adanya pengaruh pada Mind Mapping yang digunakan dalam penelitian ini.

\section{PEMBAHASAN}

Berdasarkan pengujian hipotesis dari nilai posttest dengan menggunakan uji-t diperoleh $t_{\text {hitung }}$ lebih besar dari tabel, yaitu 3,019 > 1,67, sehingga hipotesis nol (Ho) ditolak dan hipotesis (Ha) diterima. Perolehan nilai $\mathrm{T}_{\text {hitung }}$ yang lebih besar dari pada nilai $\mathrm{T}_{\text {tabel }}$ mengindikasikan adanya pengaruh atau perbedaan yang cukup signifikan antara kedua kelas. Dengan demikian dapat disimpulkan bahwa pembuatan Mind Mapping berpengaruh terhadap hasil belajar PKn siswa. Apabila $\mathrm{H}_{\mathrm{a}}$ > Ho terdapat pengaruh yang signitifikan perlakuan variabel bebas (Mind Mapping) (Irianto, 2015: 99). Hal ini terlihat dari rata-rata hasil belajar siswa kelas eksperimen $(80,8)$ lebih tinggi dari pada rata-rata hasil belajar siswa kelas kontrol $(72,4)$.

Hasil dari analisis yang dikatakan secara parsial menyatakan bahwa ada pengaruh yang positif yang signifikan dari variabel Mind Mapping terhadap hasil belajar pendidikan kewarganegaraan siswa di
SDN 54 Anak Air Kec. Koto

Tangah Padang. Proses pembelajaran siswa dengan menggunakan pembuatan Mind Mapping lebih bebas dan aktif dibandingkan dengan siswa yang belajar dengan pembelajaran konvensional.

$$
\text { Dari kegiatan }
$$

pembelajaran dengan pembuatan Mind Mapping tersebut, siswa mampu belajar dengan bekerja sama dengan anggota kelompoknya dan bisa bertanggung jawab dengan tugas yang diberikan pada kelompoknya

Pembelajaran

menggunakan pembuatan Mind Mapping membuat siswa senang dan mudah memahami dan mengingat materi yang disampaikan guru. Dimana siswa dituntut untuk bertanggung jawab dalam pembuatan Mind Mapping. Pembuatan Mind Mapping juga dapat menggali potensi siswa dalam menyelesaikan tugas yang diberikan guru.

Pelaksanaan pembelajaran pada kelas kontrol yang diberikan pembelajaran konvensional, siswa terlihat pasif dan hanya mendengarkan penjelasan dari guru. 
Hal ini bisa terlihat ketika siswa dikelas kontrol mengalami kesulitan dalam belajar mereka tidak mau bertanya atau malu bertanya kepada guru. Mereka hanya melakukan apa yang ditugaskan oleh guru tanpa berkomentar apapun.

Pembelajaran di kelas kontrol, pada tahap awal kegiatan guru melakukan apresiasi, kemudian pada tahap eksplorasi siswa diberikan bahan bacaan yang sama dengan kelas eksperimen. Setelah itu siswa diminta untuk melakukan kegiatan membaca untuk menguasai bahan bacaannya. Dan pada tahap selanjutnya yaitu elaborasi siswa mendengarkan penjelasan materi dari guru. Ketika guru telah selesai menerangkan materi siswa diminta untuk mengerjakan soal-soal sebagai latihan. Kemudian dibahas bersama. Sedangkan pada tahap konfirmasi guru memberikan kesempatan bagi siswa untuk bertanya dan memebrikan kesimpulan dan penguatan terkait materi.

Pada kelas eksperimen, siswa terlihat aktif dan terlibat langsung dalam proses pembelajaran, guru bersifat hanya sebagai fasilitator saja. Pada tahap apersepsi, guru menggali pengetahuan siswa tentang materi yang akan diajarkan. Siswa aktif mencari informasi tentang materi yang akan diajarkan dengan menjawab dan bertanya berbagai hal tentang materi. Tahap eksplorasi, guru membuka skemata siswa tentang materi yang akan diajarkan dengan menyanyikan lagu dari sabang sampai merauke.

$$
\text { Pada tahap elaborasi }
$$

mengemukakan konsep atau permasalahan yang akan ditanggapi oleh siswa dan sebaiknya permasalahan yang mempunyai alternatif jawaban tentang materi yang akan diajarkan. Kemudian siswa dibagi LKS dan mengerjakan LKS dalam Mind Mapping yang utuh.pada tahap konfirmasi guru meminta siswa untuk memajang hasil karyanya di depan kelas dan membacakan hasil diskusinya tersebut.Pada tahap terakhir guru bersama dengan siswa menyimpulkan pembelajaran yang telah dipelajari hari ini.

Dari kegiatan tersebut, siswa kelas eksperimen lebih bebas dalam kegiatan belajar dan merasa senang serta mudah mengingat materi yang disampaikan, dibandingkan dengan kelas kontrol yang lebih terlihat pasif dan membosankan. 
Bahkan terlihat dari hasil belajarnya yang sangat berbeda antara kelas eksperimen dengan kelas kontrol.

Berdasarkan hasil analisis data posttest diperoleh bahwa hasil belajar kedua kelas berdistribusi normal. Pengujian homogenitas sesudah pemberian perlakuan menunjukkan bahwa seluruh kelas data memiliki varian yang homogen. Dari pembahasan sebelumnya dapat dilihat juga, bahwa rata-rata hasil belajar kognitif (posttest) siswa kelas eksperimen yaitu kelas VA SD Negeri 54 Anak Air Kec. Koto Tangah Padang dengan pembuatan Mind Mapping adalah sebesar 80,8 dan siswa kelas kontrol yaitu kelas VB SD Negeri 54 Anak Air Kec. Koto Tangah Padang dengan pembelajaran konvensional adalah sebesar 72,4.

\section{Berdasarkan uji hipotesis} posttest yang dilakukan dengan menggunakan uji t didapatkan $t_{\text {hitung }}>$ $\mathrm{t}_{\text {tabel }}(3,019>1,67)$, maka $\mathrm{H}_{0}$ ditolak, $\mathrm{H}_{\mathrm{a}}$ diterima. Hasil penelitian ini memperlihatkan adanya pengaruh penggunaan Mind Mapping terhadap hasil belajar pendidikan kewarganegaraan di kelas V SD Negeri 54 Anak Air Kec. Koto Tangah Padang

\section{KESIMPULAN}

Berdasarkan hasil analisis data dapat disimpulkan bahwa terdapat pengaruh penggunaan Mind Mapping terhadap hasil belajar PKn di kelas V SDN 54 Anak Air Kec. Koto Tangah Padang terjadi. Perbedaan hasil belajar pendidikan kewarganegaraan (PKn) siswa kelas eksperimen.

Menggunakan Mind Mapping dengan kelas kontrol menggunakan pembelajaran konvensional. Hal ini ditunjukkan dari perolehan hasil perhitungan uji hipotesis posttest melalui uji-t pada taraf signifikansi 0,05 , dimana thitung $>$ ttabel yaitu 3,019>1,67. Selain itu, rata-rata hasil belajar pendidikan kewarganegaraan (PKn) siswa kelas eksperimen lebih tinggi dari kelas kontrol pada materi mendeskripsikan NKRI dengan nilai rata-rata hasil belajar PKn adalah sebesar 80,8 untuk kelompok eksperimen dan nilai rata-rata hasil belajar PKn 72,4 untuk kelompok kontrol. Hal tersebut menunjukkan hasil belajar pendidikan kewarganegaraan (PKn) di kelompok eksperimen lebih baik dari pada hasil belajar 
pendidikan kewarganegaraan (PKn) di kelompok kontrol, sehingga dapat disimpulkan bahwa Mind Mapping dapat mempengaruhi hasil belajar pendidikan kewarganegaraan siswa.

Berdasarkan kesimpulan di atas, selanjutnya dapat diajukan beberapa saran yang dapat dijadikan pertimbangan, yaitu : 1. Guru diharapakan agar dapat menggunakan Mind Mapping dalam pendidikan kewarganegaraan, karena penggunaan Mind Mapping ini dapat berpengaruh positif terhadap hasil belajar siswa. 2 . Guru dapat menggunakan inovasi model-model, 3. Pembelajaran, khususnya guru dapat menggunakan Mind Mapping untuk lebih meningkatkan pemahaman siswa akan materi dan dapat membuat siswa lebih aktif dalam belajar pendidikan kewarganegaraan (PKn) 3. Bagi peneliti lain yang berminat melakukan penelitian mengenai penggunaan Mind Mapping, diharapkan mengadakan penelitian lanjutan dengan dapat mengantisipasi kendala-kendala yang terjadi.

\section{Daftar Rujukan}

Buzan, Tony. 2004. Buku Pintar Mind Map. Jakarta: PT Gramedia Pustaka Utama.

Depdiknas. 2006. KTSP Jenjang Pendidikan Sekolah Dasar. Jakarta : Depdiknas.
Irianto, Agus. 2008. Statistik Konsep Dasar dan Aplikasinya. Jakarta: Kencana.

Istarani. 2012. 58 Model Pembelajaran Inovatif.

Medan:Media

Persada.

Sugiono. 2009. Metode Penelitian

Kuantitatif, Kualitatif dan $R \& D$. Bandung: Alfabeta

Sugiono. 2012. Metode Penelitian Pendidikan.

Bandung: Alfabeta. 
15 | e-Journal Inovasi Pembelajaran SD | http://ejournal.unp.ac.id/index.php/pd | 